\title{
MAU-MAU WAR RITUALS AND WOMEN REBELS IN KIRINYAGA COUNTY OF KENYA (1952-1960): RETRIEVING WOMEN PARTICIPATION IN KENYA'S STRUGGLE FOR INDEPENDENCE
}

\author{
Julius Gathogo \\ Senior Lecturer, Kenyatta University \\ Research Fellow in the Research Institute for Theology and Religion \\ University of South Africa \\ jgathogom@yahoo.com
}

\section{ABSTRACT}

The Mau-Mau war of independence in Kenya was fought after the returnees of the First and Second World Wars (1919-1945), who were mainly Christians, succeeded in politicising the black majority in the then Kenyan colony (1920-1963) to demand justice across the colour divides, as a religio-ritual duty which climaxed in oaths. The first stage of the war was seen in the change of contents in the African ritualistic dances that young men and women had gotten used to. In time, the love songs became political and/or patriotic songs that prepared people for a major war that was in the offing. The second stage was the secretive binding oaths. The third stage was the repositioning of the rebels in terms of forest fighters, the combatants, who were to engage the British government in guerrilla warfare. The third stage also saw some rebels positioned as spies, oath administrators, resource mobilisers, food suppliers to the forest fighters, among other offices. In all these duty allocations within the rank-and-file of society, it is critically important to ask: Were these ritualistic oaths a poor imitation and/or mockery of ecclesiastical Eucharist? Were men and women fighters acting from a just war theory? What role did women play in this all-important war that inspired other liberation movements in Africa and beyond? In Kirinyaga County of Kenya, were there women combatants and/or supporters of Mau-Mau rebellion (1952-1960)? The materials in this article are primarily gathered through archival sources and through interviewing some of the participants.

Keywords: Women rebels; women Mau-Mau freedom fighters; ritualistic oaths; Kirinyaga County of Kenya

\section{UNISA $\cong$}




\section{INTRODUCTION}

Mau-Mau is the derogatory name (though ironically, the most commonly accepted phrase of the rebels) for the Kenya Land and Freedom Army (KLFA) which waged guerrilla warfare against British colonialism in Kenya from the late 1940s, and reached its climax in the early 1950s until constitutional independence was achieved in 1963. To commit the disenfranchised black populace fully, the elite-leadership began by administering various types of oaths to the recruits in the late 1940s. In these ritualistic oaths, where various concoctions (that included water mixed with uncooked goat meat) were used among other paraphernalia, women's contribution is clearly evident. In these ritualistic oathing sessions, a person was solemnly made to swear that he or she would obey whatever the Mau-Mau war council told him to do; be it killing or joining others who were waging guerrilla warfare. Most importantly, he was to uphold the Mau-Mau secrets even to the point of death (interview Maceru 31/01/2014). Curiously, while the mundu-mugo (the oath administrator) who conducted the oath was clothed, his recruits were always forced to partake while naked. Was it a way of scaring the possible traitors that the curse would befall them? Was it a scaring gimmick? Considering that the Kenya colony was basically a Christian state, were these "Christian" combatants and oath administrators attempting to demonstrate the resilience of African religion amidst mass conversion to the new faith (Christianity)? Was it meant to go beyond the Holy Eucharist that was being administered in the European missionary churches?

Critically important is the fact that both the church (mainly the Presbyterians and the Anglicans) and the colonial government teamed up to gallantly oppose the ritualistic oaths which were seen as blasphemous, mockery to the holy communion, foul, and indeed satanic. Considering the evangelical backgrounds of the two churches, the passionate dismissal of Mau-Mau rituals can be seen from that backcloth. At one stage, the two churches refused to allow children from families that were associated with the movement; a phenomenon which saw the Catholic Church gain numerically as it was open to everyone. In view of this, 24 senior lay and ordained church leaders from the Kikuyu nation of Kenya met in Nairobi, on 27 January 1954, and condemned Mau-Mau activities as a threat to peace that God gives freely (interview Matene 01/02/2014). They were led by the Hon. Muchohi Gikonyo, M.L.C., and the Hon. E.W. Mathu, M.L.C. This can be explained thus:

- Those who represented the present day Kirinyaga and Embu counties (which were then one Embu district) were lay Anglican Church leaders: Chief Stephen Ngigi Machere and Chief Richard Githae (interview Matene 01/02/2014).

- From the present day Nyeri County, the delegates were mainly Presbyterians: Senior Chief Muhoya, the Rev. Charles Muhoro, and Chief Eliud Mugo.

- From the present day Kiambu County, which had most of the anti-Mau-Mau delegates, were: Harry Thuku, Chief Magugu Waweru, the Rev. Wanyoike Kamawe (Presbyterian), Councillor Mbira, Chief Kibathi Gitangu, the Rev. William Njoroge 
(Anglican), Canon Samuel Nguru (Anglican), Div. Chief Josiah Njonjo, and James S. Gichuru.

- The delegates from the present day Murang'a County were: Ex-Senior Chief Njiri Karanja, M.B.E., Chief Ignatio Murai, the Rev. Elijah Gachanja (Anglican), and Chief Samuel Githu.

- From the vast lands of Rift Valley (refer to Narok, Nakuru, and Laikipia Counties), Permenas Kiritu, Chief Chrysostom Kihagi, J.F.G. Kanyua and Chief Zedekiah Wambugu were the delegates (interview Matene 01/02/2014; CMS: G3AS/1923/9).

As can be deduced from the above, the Mau-Mau war of Kenya's independence was not just a protest against colonial injustices, but also the marriage of convenience between the church and the colonial government. Hence a common saying had emerged that there is no marked difference between the European missionaries (and church leadership in general) and the European settler-farmers who were equally racist and brutal (gutiri muthungu na mubia) (Kanogo 1987). Considering that the 24 anti-Mau-Mau signatories did not have any women therein, this leads us to further ask ourselves: Where are the voices of women on both sides of the socio-ecclesiastical divide? Does it mean that even the freedom movement itself did not have women therein? Were there clear women contributions in the Mau-Mau rituals of oath administration and the partaking of the oath in general?

\section{THEORETICAL FRAMEWORK}

This article is theoretically informed by John Walton's (1984) theory of Reluctant Rebels. In his book, Reluctant Rebels: Comparative Studies of Revolution and Underdevelopment, Walton analyses national revolts on three continents. That is, the Huk rebellion in the Philippines (1946-1953), the Colombian civil war known as La Violencia (1946-1958), and the Mau-Mau revolt in Kenya (1952-1960). For him, the Mau-Mau "heat" died down after the capture of their de-facto leader, Field Marshal Dedan Kimathi wa Chiuri in 1956. In his view, it is not underdevelopment or the class struggle that causes revolts per se; rather, it is the political consciousness, articulated along religio-ethnic lines that really pull the revolutionary trigger. Without the pivotal role of the elites, the revolutionary wars would not take place, as happened in the Kenyan case where the returnees of the Second World War (1939-1945) ignited the revolutionary fire. In so doing, Walton raises the bar on the leadership of such revolts, though the contribution of women is largely silenced by patriarchy to an extent that one may be tempted to think that it was not there at all. Or are women content with oppressive environment and/or not courageous at all? Walton's theory comes out clearly in this article when we appreciate the role of oath administrators in Kirinyaga County (1940s and 1950s), who were indeed the elites of the time. Clearly, they understood the psychology behind oath-taking as a compulsory duty. In other words, the rank-and-file of society was not given room to choose to partake or not partake the oath. The leading 
elites, as the vision careers, were the ones who brought the political consciousness to the reluctant seekers of independence. In the analysis, the reluctant populace easily found themselves in a war of independence.

\section{TYPES OF RITUALISTIC OATHS}

At this stage, it is important to briefly consider the various types of ritualistic oaths that were undertaken by the rebels (Mau-Mau binding oaths).

\section{a) Mungururio oath}

This type of oath was for everybody in reserves. It was set as a psychological preparation for everyone to prepare for a major contest.

\section{b) Mbatuni oath}

It was for those who were going to war. It was indeed a sacrament of strengthening (umiriria); and indeed, the second oath for everyone.

\section{c) Mtogo kwa Mtogo oath}

This was set out for a very few people. Indeed, it was only undertaken in the forest by the Mau-Mau rebels. It was meant to ensure that only the combatants understood certain military and coded languages and phrases. It was never given to the reserve people. In turn, it encouraged fighters to fight with more confidence. In using the coded words, Mtogo kwa Mtogo, they also had other phrases such as Kahenri kwa kahenri among others, the rebels wanted to preserve the uniqueness of their organisation. Kahenri meant razor blade; while Mtogo meant the gun. By use of such repetitive phrases, the coded language called the rebels to come and fight whenever the situation demanded.

\section{d) Muma wa Gikundi oath}

This type of oath was administered to war committees/councils. It was geared towards ensuring that some secrets were not shared out, even to fellow junior fighters. Indeed, it was also called atongoria oath. Sometimes, it could be decided, "let's have another oath now that we have grown weary, hence, we do another one." It was still a form of Mbatuni oath or Mbaara oath. It meant that the partaker of the oath was ready to go for war at any time, whenever he or she was called upon or advised by any of the various war councils formed across the various parts of Kenya. Indeed, it was a special kind of oath for forest fighters, and never to the reserve people. 


\section{THE NATURE OF RITUALISTIC OATHS IN KIRINYAGA COUNTY}

In my interviews with one of the surviving Mau-Mau Generals in Kirinyaga County, General Matene (1922- whose real name is Nyamu wa Muriakori), most of the initiates were not fully conversant with the politics of the day (interview Matene 01/02/2014). They were nevertheless forced to undertake the Mau-Mau ritualistic oath, as failure to do so would have led to suspicion, mistrust, and/or killing by the rebels or the general society. General Matene, who was among the first Mau-Mau oath administrators in the present day Kirinyaga County, had by the late 1940s administered the binding oath to people from all walks of life. In his recollections, most of those who were brought to him for compulsory oath-taking included Christians, teachers, peasant-farmers, some local sub-chiefs and all categories of people. In his view, some of the "captured" initiates were not psychologically prepared to undertake the oath, but the politics of the day dictated that "every African, man or woman, must take the oath of loyalty to the cause of freedom, and swear that he or she would do the best he or she can to reclaim the lost lands" (interview Matene 01/02/2014). In view of this, the article seeks to address the question: Were there women rebels and/or combatants in the Mau-Mau war of independence in Kirinyaga County? In other words, how did women contribute in the Mau-Mau rituals during Kenya's war of independence, and particularly in Kirinyaga County?

In regard to the motivation for the research on the role of "Christian" women in the Mau-Mau war (1952-1960), the article is largely motivated by the South African freedom icon, Nelson Mandela (1918-2013) who highlighted its pan-African role upon his release in 1990. After his 27 years (1963-1990) of imprisonment, he visited Kenya in July 1990, and openly recognised the role of Mau-Mau in his own inspiration as a freedom fighter. Accompanied by Winnie Mandela, Mandela extolled the role of women in liberation struggles, and especially in the Kenyan case. As an eye witness, I heard Mandela say (and as quoted in Muiru 2013) thus:

In my 27 years of imprisonment, I always saw the image of fighters such as [Field Marshal Dedan] Kimathi, [General] China, and others as candles in my long and hard war against injustice ... It is an honor for any freedom fighter to pay respect to such heroes.

In this July 1990 visit, Mandela publicly asked the erstwhile president, Daniel Moi, about the whereabouts of freedom fighter Dedan Kimathi's widow, Mrs Mukami Kimathi; a situation that embarrassed the system which ignored such people after independence. Considering that Mrs Kimathi was languishing in distant lands in Nyandarwa County, Moi's government was at pains to explain to the saintly Mandela about her whereabouts. Without Dedan Kimathi, who was hanged after capture in 1957, the focus since then turned to the ailing Mrs Kimathi, who was later recognised by the state and the church since 2003 when the opposition party under Mwai Kibaki took over from the ruling 
party. This further drives us to seek to know the contribution of women themselves in the Mau-Mau rebels' discourses.

\section{WOMEN IN THE MAU-MAU MOVEMENT IN KENYA}

Certainly, Mau-Mau historiography has tended to ignore the role of women as revolutionary participants. They are presented as mere spectators. Women played critical roles in this revolution's success because "its ultimate triumph depends upon successful appeals to women and families to supply resources to nourish it. As primary producers, women are essential for a sustained challenge to the state to be successful." To this end, women did not only provide food to the rebels, and administer oaths, but some even joined the rebels and fought alongside men. In particular, when General Kubukubu was ambushed and shot dead at Kianjokoma-Embu in September 1956, he was with a woman combatant. They both died the same day from bullet wounds. Sadly, the researcher was not able to gather enough information regarding the woman combatant who was killed together with General Kubukubu, owing to patriarchal constraints. Indeed, interviewees were not interested to tell more about this woman.

Tabitha Kanogo (1987) in her book, Squatters and the Roots of Mau Mau 19051963, contends that women were often the Mau-Mau stronghold in families. ${ }^{2}$ Clearly, husbands could only take the oath along with their wives or remain silent about their beliefs or they could become easy targets and be killed by the rebels. Initially, as men fled to the forest, women were not allowed. In time, the rebels realised that women were valuable allies who could not be ignored in the goal of delivering the promise of freedom. To begin with, they began to allow single and widowed women, who were trusted to remain secretive. In the analysis, some became forest fighters. Some were inducted into the Inner Secret Council, which was formerly for men only. Kanogo has cited one woman by name, Wanjiru Nyamarutu, who was known as a "hard core" rebel. She was respected by all rebels, both men and women. She was incharge of the distribution of food and even gathered intelligence. In her view, she changed the perception on how other rebels viewed women and eventually appreciated their role in the revolutionary movement. $^{3}$

While Kirinyaga County does not boast of top ranking women-Mau-Mau women leaders at the level of a field marshal, a general and so forth - the neighbouring Nyeri county boasts of Field Marshal Muthoni wa Kirima (1930- ) who continued to wear Mau-Mau dreadlocks that she used to wear while a forest fighter, 50 years after Kenya's

1 Mary Ann Tétreault, "Women and Revolution: A Framework for Analysis," in Women and Revolution in Africa, Asia, and the New World, Mary Ann Tétreault, ed. (Columbia, SC: University of South Carolina Press, 1994), 4.

2 Tabitha. Kanogo, Squatters and the Roots of Mau Mau 1905-63. Nairobi: Heinemann Kenya, 1987, 143-149.

3 Tabitha. Kanogo, Squatters and the Roots of Mau Mau 1905-63, 143-149. 
independence (1963-2015). Being the only woman to be accorded the title of a field marshal, Muthoni must have been a tough fighter. ${ }^{4}$

Major Judge recalls one woman Mau-Mau leader, Wambui wa Kanyari whose rebel name was Matron. She came from Ngerwe village, Ngariama location. In the Mau-Mau administrative structure, she was in the Department of Medicine. She was a sister to Major Kingkong, whose real name was Elijah wa Kanyari. She was originally from Kiambu but had settled at Njukiini (Ngerwe), Ngariama location. As a nurse, attending to the Mau-Mau rebels in the forest, Matron cleaned syringes and generally handled medicines. Some women would come to the forest while pregnant and would find Matron who took care of them. Interestingly, it is Ngariama location and Embu side of the then Embu district that produced more women forest fighters than other places. Others would come to the forest with a child or remotely got pregnant after a rape ordeal while in prison. Matron would mid-wife the births of the children born while in the forest. Some women shot in some sensitive areas of the body were nursed by her.

Major Judge (interview 17/01/2014) recalls that he and his colleague, Abdulla, once treated a lady by the name of Njoki, who had been shot during the Battle of Kangema of 1953, in the present day Murang'a County. She had been shot twice in her private parts. They would have preferred to see a woman nurse treating her rather than a male nurse. Indeed, Matron's rank was that of a Major, as forest nurses were put in that level. Hence, women in Kirinyaga-Embu's Haraka platoon also rose to such senior levels. Concerning the Battle of Kangema where one wounded woman rebel had to seek treatment among the rebel nurses of Kirinyaga, the forest fighters had attacked administrative police lines, burned cars and petrol tanks among other belongings that were owned by the government.

Another case of a woman combatant is Haraka. Although the first platoon that was formed to operate within Embu-Kirinyaga side was called Haraka, there was also a lady by the same name. She was also one of General Kassam's body-guards. She also served food to Kassam. She could also be sent to carry things for Kassam. The only item that she didn't carry for Kassam was the gun. She came from Ngariama (Kirinyaga East). Another woman within the rebel ranks was called Kahonoki. She was a very young woman, unlike Haraka and Major Matron. She had a brother by the name of Musyoka, from Kamba ethnic nationality living in Mwea. She was based in Njukiini forest. She was just a rebel fighter like her male counterparts. There was also Jerena wa Maheni, also called Muthoni from Kiandumo, Ngariama location. She was alive by 2 March 2015 when the researcher was conducting his interviews with various people. She was staying at Kamugunda, as a married elderly lady. As the Mau-Mau began the process of suing the British government for war atrocities in and around 2004, Muthoni feared that the British could not compensate. She teamed up with others to oppose the whole idea

4 Micere Githae Mugo, Muthoni wa Kirima, Mau Mau Woman Field Marshal: Interrogation of Silencing, Erasure, and Manipulation of Female Combatants'Texts, SAPES Books, 2004. 
of suing the British. Nevertheless, she was a good forest fighter in the 1950s that scored her goal with a measure of success.

Another woman rebel was Bandi wa Kamau. She used to bring food to the MauMau soldiers while in the forest. In 1953, she played a key role in guarding the Mau-Mau oath. She could also team up with others to lure mature girls to the oathing sessions. In wooing women to the oathing sites, Bandi was trying to avoid breaking the African (Kikuyu) traditions which discouraged women from administering ritualistic oaths. They also discouraged ihii (uncircumcised boys/men) from partaking the oath. ${ }^{5}$ Even though the old Mutira location could not boast of women combatants in the forest as such, as in the case of Ngariama location, it had a number of women Mau-Mau detainees. This includes Gladys Wanjiku, who will be considered in detail later. Another Mau-Mau woman detainee is Wamarwa, the wife of Mugambi wa Maria, also called Mugambi wa Kareu from Kiangoma. Mugambi was a combatant in the forest and was killed while a fighter in the forest. In regard to Madam Wamarwa, she was detained at Kathigiriri prison, Mwea division of Kirinyaga County. By 2015, she was alive. Ironically, she was released after her husband's death and got married to Kanegeni, a home guard.

Although she hailed from the notorious Kamuiru area that produced the fiercest fighters, Wamarwa got remarried. Her new home was situated at Kiawaruguru, near Mutitu Chief's camp, now the headquarters of Mutitu division. According to Gladys Wambura Munene (interview 03/05/2015), Wamarwa, the daughter of Riua, was captured when taking food to Mau-Mau at Riagicimba, Kanjie near Kibingo Town. There were other women detainees from Kamuiru area of Mutira location, such as Mwarakabugi (daughter of Kabugi), the wife of Kibonge wa Njibu. She was with Wamarwa when they were caught as they were taking food to the rebels in the forest. Both were detained at Kathigiriri prison in the mosquito-infested area of Mwea, of the present day Kirinyaga County. Another woman was Mwaragakuru (daughter of Gakuru) from Kiunyu near Kamuiru Anglican Church. Her other name was Mama Macharia. Others are Gladys Wainoi, the "official" wife of General Chui, Wanjiku wa Mararo among others.

Another critical woman Mau-Mau leader in Mutira location of Kirinyaga County was the third-born child of Mzee Mararo wa Matumbi, where General Chui was the first born, Mary Wangari Mararo (1932- ). While their fourth born, Joseph Murage (1938- ) was the rebel's spy in the village, Mary Wangari Mararo joined the fighters in the forest, though briefly. She, however, became their cook. In turn, she would cook food and take it to the combatants so as to feed them as they carried out what was considered the "national duty." Indeed, she was the chairperson of girls who were taking food to the

5 According to Major Judge, the 1969 oath was meant to unite home guards and Mau-Mau; and it did not succeed. Mau-Mau saw it as fake oaths. When clergy led by Cardinal Otunga went to see Kenyatta over this 1969 oath, Kenyatta got a phone, called the then Attorney General, Charles Njonjo (1920- ), and asked him what was happening. Njonjo asked Kenyatta "Is the Anglican Bishop Kariuki there?" Kenyatta replied, "No." Njonjo then said, "Tell them to go away." The story ended there. Hence reconciling the former home guards and the Mau-Mau rebels has always proved tricky. 
rebels in the thick forests. She had a secretary who recorded events as they unfolded. She was at one time detained at Kagumo, at a building that had been rented to lock up such women. When her mother was detained she was tasked with the responsibility of taking care of her young siblings, namely, Murage, Muriithi, and Saweria.

A key leading woman rebel, whom the study has considered in length, is Lydiah Wanjiku. From credible sources, she used to be called Kirunda wa Kinuthia when she was young. She later got married to General Chui (then called Kibara wa Mararo) and had a son by the name of Manegene. While General Chui, one of the Mau-Mau leaders of Embu districts' Haraka platoon, was engaging the colonial government with his lightning attacks, she was also, in some cases, part of it. When she retreated to the village, she was captured, tortured and taken to several detention camps. She was only released after the killing of General Chui. In the researcher's one-on-one discussion with her (Wanjiku interview 03/05/2015), she admitted being imprisoned because of her association with General Chui, though she did not admit that she was ever married to him. While in prison, she would be threatened from time to time, thus: "We shall release you when you tell us the whereabouts of General Chui and his gun." She was beaten senseless and only thanked God for being alive during the May 2015 interviews.

Wanjiku recalled that she was directly arrested by Senior Chief Stephen Ngigi wa Machere in 1950s. She was accused of cooking for General Chui. When the Chief brought her to the prison warders, he said, "I have brought to you another Mau-Mau." It is from there that she was imprisoned at the mosquito-infested Karaba prison, in the present day Embu County (1955 to May 1956). She described General Chui as not too talkative, but politically and militarily alert. She also explained that while Chui hated the fake Mau-Mau General Mbaka, who was using the opportunity to sneak girls to the forest so as to defile them, he liked Munene wa Gatuki as a serious Mau-Mau rebel. He was a rebel from Mugaya, three kilometres from Kamuiru shopping centre. Apart from his passion for freedom and the hatred for European oppressors, Chui was ironically too brown; such that he resembled the Europeans. As a confidant to General Chui while rebel Lydiah Wanjiku (interview 03/05/2015) before General Chui was shot at Irura-ini ria Kiania or the mushy area near Kiania Town in May 1956, the colonial government had by 1955 announced an amnesty on Mau-Mau rebels; hence, she returned to the reserves and did not have to be killed or arrested. This was not possible for Chui because the Senior Chief, Stephen Ngigi wa Machere, had decreed that even if General Chui returned and indeed surrendered, he would still be killed.

Upon her release, she got married to Mr Murage from Kiarugu area of Mutira location, Kirinyaga. In an interview with her on 3 May 2015, she was reluctant to disclose that she was once married to General Chui, owing to the fact that she remarried after Chui's killing. We could, however, gather more information from other credible sources about her progression in life. She nevertheless explained thus:

We were marrying off girls during the late 1940s. The process went hand-in-hand with traditional dances, which were basically love songs. In time, we heard that there was oath-taking that was 
ongoing. When we were dancing with young men we suddenly realized that these dancing songs changed to serious political issues. We could now hear some of these songs now bringing in issues such as "we are seeking independence." We sang Mucung'wa dance which used to say "you Germans and British be aware that war is coming." We noticed the changing of dancing styles. It is from there that oath-taking became the vogue. We would now go to dance at night. Later, the old songs disappeared and songs of freedom became the fad. (Wanjiku interview $03 / 05 / 2015)$

Previously, they used to participate in African indigenous rituals by singing Nduumo dance in the months of January and February, and Mucung'wa dance in the latter part of the year. But now, Mucung'wa dance, which was highly politicised, became the most dominant dance, especially after the Second World War (1939-1945). In Lydiah Wanjiku's observation as an eye witness, the returnees from the war came with the politics of independence. They had realised that the European was not superior to the African, as they had fought their clan wars.

\section{WOMEN CONTRIBUTION THROUGH WAR SONGS AND DANCES}

As the Mucung'wa dance enlightened the people about the architectural designs of the struggle for independence, the government eventually took notice of the struggle song and dance. In time, it became a protected song and it was not allowed to sing the song during the day time. It was, however, sung in a very secretive way. Following the government's realisation that the Mucung'wa dance was nothing but a political dancewith a political message that resonated well with the concerns of the locals - it ordered a crackdown on those who were singing it, even in ordinary home circumstances. As a result, a number of people were arrested, tortured, and/or jailed.

Characteristically, as the villagers sang Mucung'wa dance, they would tie themselves to njingirici (small but noisy containers full of broken bottles). In her recollections, Lydiah Wajiku (interview 03/05/2015) noted that Kibicho wa Rukenya came from Nairobi and would constantly tie njingirici around his leg and dance heartily to the amusement of the villagers. He would walk from Kamuiru village to Kagumo town with noisy njingirici being tied around his legs as he sang and danced the Mucung'wa dance, which was a wake-up call for villagers to see struggle for freedom and dignity as the way forward. And because of its coded language, it was not initially understood even by the locals. Upon realising that he was being targeted by Home Guards (Ngati) for arrest and its resultant torture, he retreated to the forest where he was killed a few months later by the colonial forces as he tried to sneak to the village to look for food. Nevertheless, his passion for Mucung'wa dance and the message he was communicating show how the Africans in Nairobi had influenced one another regarding the quest for freedom. As he came to the village, he found that the political elites had not effectively brought the message of freedom. He chose to do it and eventually lost his life. 
In Lydiah Wanjiku's (interview 03/05/2015) observation, the Mau-Mau ritualistic oath, and the whole philosophy behind the struggle for freedom, in Kirinyaga County and indeed the entire Embu district, were championed by the youths, especially those who were politicised while looking for jobs in Nairobi city. Others were returnees from the Second World War (1940s). Others were the poorly educated youths who had fallen out with the church; some expelled for indulging in African ritualistic and cultural dances which were seen as pagan. Like the founders of the African instituted churches, who were dissatisfied with discrimination in the European missionary churches or the mainline churches (refer to Methodists, Presbyterians, Anglicans, etc.), the youthful generation in the 1940s and 1950s had similar concerns; hence Mau-Mau rituals provided another avenue in their quest for identity.

As the elderly grew pessimistic, the youths gallantly pushed the freedom agenda passionately. Later, parents were invited in the partaking of the ritualistic oath. The case of Kibara wa Mararo, later General Chui, is a case in point. In the case of MauMau General Chui, he is the one who convinced his father, Mzee Mararo wa Matumbi, to not only partake in the Mau-Mau oath, but also lectured him about the rebels' politics, visions, land policies, and policies on farming, family, ethnic composition, and governance among other things. Indeed, young men first kept it as a secret and only shared it with parents after it became the vogue. Whenever anyone was told that independence would come after the oath, most people readily accepted it. In the homes where oath-taking was administered, everyone was forced to partake in the oath and sternly reminded to keep the secret or else be killed for exposing others to the "enemy". They used coded language to conceal their issues, which was indeed part of their rituals. Coded language was also used to identify characters who were betraying others to the colonial authorities. Such coded languages included, saying: "Haba Heba ngukumi", meaning, "here we have bedbugs". Bedbugs referred to non-oath partakers (interview Maceru 31/01/2014).

Characteristically, any European belt or iron-like buttons were removed while one was taking an oath. This compares with the partaking of the holy communion in the church where partakers were requested to first cleanse themselves from all wrong doings to their neighbours, forgive those who had wronged them, repent of their sins, and indeed seek God's favour before they partake in the Christian ritual. In the case of Mau-Mau rituals, items that "glorified" the view that "white is good, black is bad" were shunned in the process. Even European names such as Julius, John, Wellington, Joyce, Jane, etc. were shunned (interview Wanjiku 03/05/2015). Hence their form of decolonising the mind began with the idea of keeping away European styles of living, European ecclesiology, and European religiosity among other concerns. Ironically, they could not perfectly do it, as even the clothes they were wearing, were indeed Western attires and/or garments. Indeed, there was too much Westernisation that could not be isolated in their new rituals and their discourses of freedom. This also applied to women administration centres, where women administrators of the oath demanded their fellow women to shed European attires. As noted, there were challenges as well. 
Whenever home guards discovered the homes where the ritualistic oath was taking place, they would always rush there and ultimately burn such houses and/or African huts. After ensuring that the whole household had taken the ritual oath, the rebels would organise people in a manner that the government would not detect. To do this, they would create chains of people that carried out different tasks. Some were Mau-Mau spies in churches, government offices, chiefs' camps and other social gatherings. Others were commanders and so forth. In time, the "converted" parents began to cook more food than usual as young women took food to the forest in disguised ways. Except for limited cases, the rebels were so disciplined that they could not molest the girls sexually and/or socially as penalties were heavy for those who tried to do so. In any case, all Mau-Mau combatants (both men and women) were requested to avoid sex during the time of war as "it was a sacred moment" (interview Maceru 31/01/2014). Critically important is to appreciate that boys were not assigned the duties of taking food to the forest. Nevertheless, they were strategically positioned to protect women, girls and the society in general. Surprisingly, "God had removed tough animals such as leopards, lions etc. that would attack women as they took food to the combatants in the forest" (interview Wanjiku 03/05/2015).

Lydiah Wanjiku, the ex-combatant also regretted that the Mau-Mau war brought economic losses on industrialisation and agriculture in Kirinyaga County, and its effects could be felt 63 years later (1953-2016). In an interview with the researcher (Wanjiku interview 03/05/2015), she noted that when the Europeans began a cabbage and carrot factory in Kerugoya Town that supplied tinned food to the combatants in the Second World War (1939-1945), it died out when the Mau-Mau war reached its climax in 1953. The collapse of the cabbage and carrot industry can probably be accounted on three grounds. One, it was not possible for Europeans to operate it when the rebels were targeting them with arbitrary shootings. Two, the suppliers of the raw materials were not effectively able to deliver the goods owing to the ongoing war, and could also not be trusted by both the Europeans and the rebels. Third, with the end of the Second World War (1939-1945), no more canned foods were needed in huge quantities; hence the factory could not stand the test of time.

Nevertheless, Lydiah Wanjiku's concern that after the collapse of the carrot and cabbage factory in Kerugoya Town, in the 1950s, no one knew where the machines went. In her recollections, she noted that the factory began well, bought carrots and cabbages from the local residents and indeed, the business improved. Is the Mau-Mau war to blame for this? Did the government close it as a measure of impoverishing the locals and indeed weaken the rebels who got financial and other material support from the locals, both men and women? It is ironic that the now ramshackle buildings were taken over as the headquarters of the police while the then Kirinyaga District Commissioner (DC, now County Commissioner) took the residences of the European managers of the factory as his official residence. 


\section{WOMEN AND MEN AS EQUAL FIGHTERS}

According to General Matene (interview 01/02/2014), the war was fought by both the people who were at home (mainly women) and those who were in the forest. Some people who fought from the home fronts (women) were affected even more than those who were deep in the cold forests. They were harassed by Mau-Mau rebels, especially when their "faith" in the freedom struggle was doubted. They were harassed by the government and the home guards who ironically did not guard; and who saw them as the real custodians of the rituals. They were harassed by the fake Mau-Mau rebels who were loosely called Komerera (fake rebels), and whose agenda was to harass young women sexually. Certainly, genuine Mau-Mau would from time to time discipline Komerera (pretending/fake Mau-Mau rebels) by hanging them on trees after thorough beatings. Gladys Wambura Munene (interview 03/05/2015) recalls one incident in 1954 when General Chui heard that Komereras were harassing women sexually. Immediately, he came with his junior rebels and thoroughly beat them up. In Matene's view (interview 01/02/2014), women suffered even more than men in the struggle for independence; for everyone was looking for freedom and land (wiyathi na ithaka) that had been taken away by the Europeans. Whenever the colonial soldiers looked for rebels, they would find women at home and eventually harass them out of frustration, particularly after failing to meet up with their husbands. Clearly, the nature of the rebels was such that it included men and women, forest-fighters and fighters from the home front. The war was indeed fought from various fronts and no single group will ever claim credit over others. Certainly, women had made a very valuable contribution!

\section{COMMITTEE FOR RESTORATION OF PEACE FORMED}

As more Mau-Mau rebel leaders were captured either dead or alive, and as the colonial government spent a lot of money on working to eliminate the rebels, the need to stop the war by all means was seen as a top priority. To do this, the colonial government in 1955 formed the Committee for the Restoration of Peace. Interestingly, when Kiama-gia-gucokia-thayu or the Committee for Restoration of Peace was formed in late 1955, women were included. This peace committee, that came after the colonial government, realised how costly the war was becoming and it was mandated with the role of searching for the rebels in the forest; that is, to convince them to pursue their ideals through peaceful means and not through war. During this period, a religious outfit called the Moral Rearmament (MRA) for peace, which was led by an ex-Mau-Mau detainee, Nahashon Ngare Rukenya, was formed in Europe in 1938 by an American evangelist Rev. Frank Buchman. The MRA played a pivotal role in reconciling the two antagonistic groups (pro and anti-colonial government). In the MRA, Ngare-Rukenya enlisted the services of women, especially from late 1958, and peace was successfully restored as more Mau-Mau soldiers were released from the various detention camps in 1959 and 1960. 
In this regard, women played a critical role as combatants and ultimately in the restoration of peace in the late 1950s and early 1960s. There were isolated incidents when pro and anti-colonial government African groups could not agree or see eye-toeye. In particular, when the lay Anglican Church leader, Michael Karuga, later subChief, once told people to pray for peace in 1958, they shouted in protest: "How can we reconcile with our tormentors?" (cf. Psalm 137). They were, however, sorry that at last he and the MRA brigade under Nahashon Ngare Rukenya brought peace amongst the two warring groups (rebels and the collaborators). In all these efforts, the role of women is evidently clear.

As British subjects, Kenyans (blacks and whites) were largely Christians, constituting over 80 per cent of the entire population. When women "Christians" joined the war of political independence, didn't it contradict the beatitudes as propounded by Jesus Christ in Matthew 5? Didn't they curse rather than bless their persecutors? Didn't they hate those who hated them rather than loving them? When they concealed information regarding Mau-Mau activities, were they acting from the just war theories that were propounded by the likes of St. Augustine in the third and fourth centuries?

At this juncture, it is imperative to concede that "just war theory" is the doctrine that propounds the view that war is morally and theologically justifiable through a series of criteria; all of which must be met for a war to be considered just. The criteria are split into three groups: the "right to go to war" (jus ad bellum); the "right conduct in war" (jus in bello); and "dealing with the morality of post-war settlement and reconstruction"(jus post bellum). ${ }^{6}$ The just war theory postulates that while war remains terrible, it is not always the worst option; for there are some situations where genocide and other atrocities can be prevented through war.

St. Ambrose of Milan (339-397) insisted on the need to distinguish between just and unjust wars. In his view, some circumstances might take us to war, though as a lesser of the two evils. A war that is designed to punish a wrong doer, he argued, is necessary; hence not all wars are immoral. ${ }^{7}$ Conversely, he rejected the death penalty as a means of effecting religious conformity. Similarly, Augustine of Hippo (354-430), generally considered as one of the greatest Christian theologians, was one of the first to assert that a Christian could be a soldier and serve God without any contradiction whatsoever. $\mathrm{He}$ affirmed that, while individuals should not resort immediately to violence, God has given the sword to their respective governments for good reason (Romans 13:4). St Augustine's fundamental position was that the peacemaker who wielded the Word rather than the sword was following a higher call. In other words, peaceful means, as opposed to violent means to counter colonialism could have served better for both Mau-

6 Charles Guthrie, and Michael Quinlan, "The Structure of the Tradition," (26 September), Just War: The Just War Tradition: Ethics in Modern Warfare (United Kingdom: Bloomsbury Publishing PLC, 2007) 11-15.

7 H. Lietzmann, The era of the church fathers (London: Lutterworth press, 1989), 70. 
Mau rebels, women rebels and their male counterparts; all of whom claimed allegiance to the God of Christendom and/or the acculturated Christianity.

\section{CONCLUSION}

On the whole, the article has brought to the fore key women Mau-Mau rebels, whose contributions were suppressed in the published works on Mau-Mau rituals which mocked Christian rituals and the colonial government (1952-1960). Through oral history methods of gathering such critical information, the article has been able to document their contributions and thereby shattered the stereotypes that claim that their roles were minimal. Certainly, some women were tortured in the detention camps; some left colonial jails pregnant after rape ordeals; some saw their children die of starvation as the colonial torture went to the extreme. As they cooked food and took it to the forest fighters in disguised ways, some could be ambushed, sometimes attacked by wild animals, and sometimes raped by the so-called home guards and other collaborators. In Kirinyaga County, just as in other counties in Mount Kenya region, women bore the brunt. In a nutshell, the article has helped us to appreciate the diverse causes and approaches in the Mau-Mau revolt and its resultant rituals that mocked the church rituals. In turn, it has demonstrated how the church (particularly the Presbyterian and the Anglican) was openly united against Mau-Mau ritual oath; and its freedom discourses at large. It has also displayed the nature, the philosophy behind the movement, the socio-religious factors, the socio-economic factors and the religio-political factors that informed the liberation movement. In all these political discourses, women both in and out of the church faced the brunt. Nevertheless, Christian women's contribution in the war of independence (1952-1960) did not come out clearly as theologically grounded, based on the "just war" theory as propounded by Augustine, Ambrose and others. Rather, their contribution, as John Walton's theory of Reluctant Rebels shows, was a by-product of the local elites who "incited" the populace to go to war. In other words, women Christians, like their male counterparts, were equally reluctant to demand political independence through guerrilla warfare; but were incited by the returnees of the Second World War (1939-45) who were highly militarised and politicised. The quest for freedom was certainly every person's dream, even though war was not initially the preference for women.

\section{REFERENCES}

Kanogo, Tabitha. 1987. Squatters and the Roots of Mau Mau 1905-63. Nairobi: Heinemann.

Mugo, Micere Githae. 2004. Muthoni wa Kirima, Mau Mau Woman Field Marshal: Interrogation of Silencing, Erasure, and Manipulation of Female Combatants' Texts. SAPES Books. 
Muiru, Kariuki, 2013. "Mandela was inspired by Mau-Mau's freedom war.” Saturday Nation, December 7, 2013.

Tétreault, Mary Ann 1994. "Women and Revolution: A Framework for Analysis." In Women and Revolution in Africa, Asia, and the New World, Mary Ann Tétreault(ed.). Columbia, SC: University of South Carolina Press, 1994, 4.

Walton, John. 1984. Reluctant Rebels: Comparative Studies of Revolution and Underdevelopment. Columbia University Press: New York.

\section{INTERVIEWS (ALPHABETIC)}

Maceru, Samuel Gakuo: 31/01/2014.

Major Judge (real name, Milton Munene Gachau): 17/01/2014.

Matene, General: 01/02/2014.

Munene, Wambura Gladys: 03/05/2015.

Wanjiku, Lydiah: 03/05/2015.

\section{ARCHIVAL MATERIALS}

CMS: G3AS/1923/9, Constitution of the African Church Council as revised by Delegates in Nairobi, 17 November 1922. 